\title{
Alain Sandrier, Le style philosophique du baron d'Holbach. Conditions et contraintes du prosélytisme athée en France dans la seconde moitié du XVIII siècle
}

Olga Penke

\section{(2) OpenEdition}

Journals

Édition électronique

URL : http://journals.openedition.org/studifrancesi/34786

DOI : $10.4000 /$ studifrancesi.34786

ISSN : 2427-5856

Éditeur

Rosenberg \& Sellier

\section{Édition imprimée}

Date de publication : 1 novembre 2005

Pagination : 426

ISSN : 0039-2944

\section{Référence électronique}

Olga Penke, "Alain Sandrier, Le style philosophique du baron d"Holbach. Conditions et contraintes du prosélytisme athée en France dans la seconde moitié du XVIIIe siècle », Studi Francesi [En ligne], 146 (XLIX I II) | 2005, mis en ligne le 30 novembre 2015, consulté le 20 avril 2021. URL : http://

journals.openedition.org/studifrancesi/34786; DOI : https://doi.org/10.4000/studifrancesi.34786

Ce document a été généré automatiquement le 20 avril 2021.

\section{c)}

Studi Francesi è distribuita con Licenza Creative Commons Attribuzione - Non commerciale - Non opere derivate 4.0 Internazionale. 


\title{
Alain Sandrier, Le style philosophique du baron d'Holbach. Conditions et contraintes du prosélytisme athée en France dans la seconde moitié du XVIII siècle
}

\author{
Olga Penke
}

\section{RÉFÉRENCE}

ALAIN SANDRIER, Le style philosophique du baron d'Holbach. Conditions et contraintes du prosélytisme athée en France dans la seconde moitié du XVIII siècle, Paris, Honoré Champion, 2004 («Les dix-huitième siècles», 81), pp. 589.

1 Ce livre par l'analyse des traductions, des éditions et des ouvrages originaux du baron d'Holbach comble une lacune. Cette entité est présentée dans le cadre de l'activité antireligieuse qui se manifeste à travers la production de livres et de manuscrits de la période analysée. L'auteur donne une présentation complexe du «style philosophique» du baron qu'il définit comme une démarche tenant compte des concepts, du contexte social et de la manière d'expression de l'œuvre d'Holbach. Le présent livre est divisé en trois parties selon ces grands centres d'intérêt. La répartition en chapitres permet en même temps d'éclairer les questions comme la conception de l'auteur, le choix du lecteur, les moyens de diffusion, la difficulté de publication des livres athées et la nature de l'écriture. L'étendue de l'entreprise se révèle particulièrement bien dans les comparaisons avec les philosophes contemporains comme Voltaire, «ennemi intime» à cause de son déisme et de son refus du système, mais qui milite comme lui pour la forme religieuse dont il est convaincu et qui se sert d'une large gamme d'ouvrages (notamment de l'édition de manuscrits) ou encore comme Diderot, ami et collaborateur 
mais qui diffère de lui par le style, les conceptions de publication ou le choix de ses lecteurs. La question épineuse des différentes collaborations qui caractérisent l'atelier holbachique reçoit également un éclairage fort intéressant. L'analyse des modalités d'énonciation conjointe à l'évaluation des idées éclaire un domaine peu recherché et très fertile du style philosophique. Holbach comme auteur accepte l'anonymat, le pseudonyme ou la clandestinité, son ultime souci étant de toucher le lecteur qu'il estime important de convertir à la raison. Son intention de persuader le conduit tout au long de ses traductions nombreuses, "prolégomènes» à son système. La diffusion de l'incrédulité le préoccupe dans l'édition des manuscrits (dont le célèbre Traité des trois imposteurs). La clarté et l'évidence sont visées quand il développe sa nature de l'écriture: il évite les images et lutte contre les «pervertisseurs de signes» en créant une langue à part, un système à l'intérieur duquel le vocabulaire doit être évident et soigneusement défini.

2 Une bibliographie détaillée, en partie annotée et disposée d'une manière très logique complète le vaste panorama parcouru par l'auteur et indique la place d'Holbach parmi les autres philosophes français contemporains. 